\title{
Calcium: Alpha-Synuclein Interactions in Alpha-Synucleinopathies
}

\author{
Alexandre N. Rcom-H'cheo-Gauthier, Samantha L. Osborne, Adrian C. B. Meedeniya and \\ Dean L. Pountney*
}

Menzies Health Institute Queensland, Griffith University, Gold Coast, QLD, Australia

Aggregation of the pre-synaptic protein, $\alpha$-synuclein ( $\alpha$-syn), is the key etiological factor in Parkinson's disease (PD) and other alpha-synucleinopathies, such as multiple system atrophy (MSA) and Dementia with Lewy bodies (DLB). Various triggers for pathological $\alpha$-syn aggregation have been elucidated, including post-translational modifications, oxidative stress, and binding of metal ions, such as calcium. Raised neuronal calcium levels in PD may occur due to mitochondrial dysfunction and/or may relate to calcium channel dysregulation or the reduced expression of the neuronal calcium buffering protein, calbindin-D28k. Recent results on human tissue and a mouse oxidative stress

OPEN ACCESS

Edited by: Federico Benetti, International School for Advanced Studies, Italy

Reviewed by:

Maria Dolores Ledesma, Centro de Biología Molecular Severo

Ochoa (CSIC), Spain

Plamena R. Angelova,

UCL Institute of Neurology, UK

*Correspondence:

Dean L. Pountney d.pountney@griffith.edu.au

Specialty section:

This article was submitted to

Neurodegeneration,

a section of the journal

Frontiers in Neuroscience

Received: 29 September 2016 Accepted: 25 November 2016 Published: 20 December 2016

Citation:

Rcom-H'cheo-Gauthier AN,

Osborne SL, Meedeniya ACB and Pountney DL (2016) Calcium: Alpha-Synuclein Interactions in

Alpha-Synucleinopathies.

Front. Neurosci. 10:570. doi: 10.3389/fnins.2016.00570 model show that neuronal calbindin-D28k expression excludes $\alpha$-syn inclusion bodies. Previously, cell culture model studies have shown that transient increases of intracellular free $\mathrm{Ca}(\mathrm{II})$, such as by opening of the voltage-gated plasma calcium channels, could induce cytoplasmic aggregates of $\alpha$-syn. Raised intracellular free calcium and oxidative stress also act cooperatively to promote $\alpha$-syn aggregation. The association between raised neuronal calcium, $\alpha$-syn aggregation, oxidative stress, and neurotoxicity is reviewed in the context of neurodegenerative $\alpha$-syn disease and potential mechanismbased therapies.

Keywords: Parkinson's disease, $\alpha$-Synuclein, calcium, Multiple system atrophy, Dementia with Lewy bodies

\section{INTRODUCTION: $\alpha$-SYNUCLEIN IN NEURODEGENERATION}

$\alpha$-Synuclein ( $\alpha$-syn) is a small $(14 \mathrm{kDa})$, acidic protein that is highly conserved in vertebrate species. It is primarily expressed in the presynaptic terminals of dopaminergic neurons in the olfactory bulb, frontal cortex, striatum, and the hippocampus. $\alpha$-Syn has also been observed in hypothalamus, thalamus, midbrain, cerebellum, and the pons/medulla oblongata with lower expression (Maroteaux et al., 1988; Iwai et al., 1995; Clayton and George, 1999). The normal function of $\alpha$-syn remains unknown, however, it has been found that $\alpha$-syn can interact with the lipid bilayer of neurons to prevent SNAREmediated fusion of vesicles (DeWitt and Rhoades, 2013). Cytoplasmic and nuclear inclusion bodies containing $\alpha$-syn have been found throughout the central nervous system (CNS) in

Abbreviations: $\alpha$-syn, $\alpha$-synuclein; CB, Calbindin D28K; CBP, Calcium buffering protein; CNS, Central nervous system; CR, Calretinin; DLB, Dementia with Lewy bodies; ER, Endoplasmic reticulum; GC, Glial cytoplasmic inclusion; JNK, cjun N-terminal kinase; LBs, Lewy bodies; MSA, Multiple system atrophy; NCX, Na(I)-Ca(II) exchanger; PD, Parkinson's disease; PMCA, Plasma membrane Ca(II) ATPase; PV, Parvalbumin; SNpc, Substantia nigra pars compacta; ROS, Reactive oxygen species; TMO, Trimethadione; VDCC, Voltage-dependent calcium channel; SERCA, sarco/endoplasmic reticulum $\mathrm{Ca}^{2+}$-ATPase. 
a number of neurodegenerative disorders. These are collectively termed $\alpha$-synucleinopathies and include Parkinson's disease (PD) and atypical PD, such as multiple system atrophy (MSA) and Dementia with Lewy bodies (DLB; Goedert et al., 2013; Eschbach and Danzer, 2014; Radford et al., 2014). Aggregation of $\alpha$-syn results from dynamic instability of the native structure and may be promoted by gene mutations or by environmental stressors, such as oxidative stress or metal ion concentration changes.

PD can be classified into two main groups: idiopathic PD, accounting for $85-90 \%$ of all PD cases; and familial PD, accounting for $10-15 \%$. Currently, six PD-linked mutations in PARK1/4, the $\alpha$-syn gene, have been identified that may provide important clues to the pathways that may give rise to idiopathic PD. They include the A30P (Kruger et al., 1998), A53T (Polymeropoulos et al., 1997), E46K (Zarranz et al., 2004), H50Q (Proukakis et al., 2013), A53E (Pasanen et al., 2014), and G51D (Lesage et al., 2013) amino acid substitutions that disrupt the membrane binding domain (Figure 1A). The A53T and A30P mutations also alter neuronal cytotoxicity in response to hydrogen peroxide and 1-methyl-4-phenylpyridinium $(\mathrm{MPP}+)$ treatment. Expression of these mutant isoforms significantly increased cytotoxicity in comparison to cells expressing wildtype (WT) $\alpha$-syn, which was similar to control cells (Kanda et al., 2000). Furthermore, both mutations showed increased fibril formation compared to WT (Conway et al., 1998, 2000; Narhi et al., 1999). E57K: mThy-1 human $\alpha$-syn transgenic mice with increased oligomerisation of $\alpha$-syn had decreased vesicles, synapse, and neuron degeneration in comparison to wildtype controls and E57K mice expressing lower levels of $\alpha$-syn (Rockenstein et al., 2014). Gene duplication (ChartierHarlin et al., 2004; Ibanez et al., 2004) and triplication of $\alpha$ syn (Singleton et al., 2003) has also been found in familial $\mathrm{PD}$, implicating increased expression of the wild-type protein. Recasens et al. (2014) have demonstrated that $\alpha$-syn species

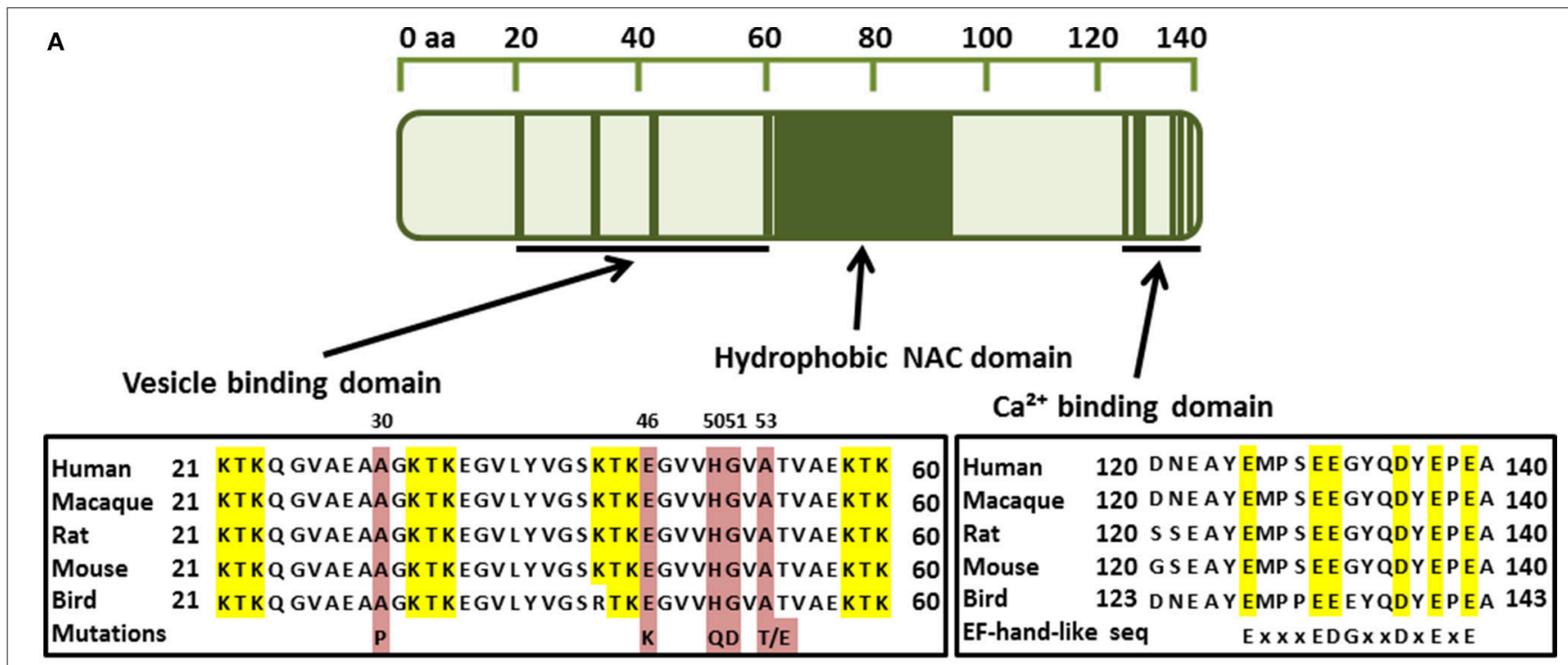

B
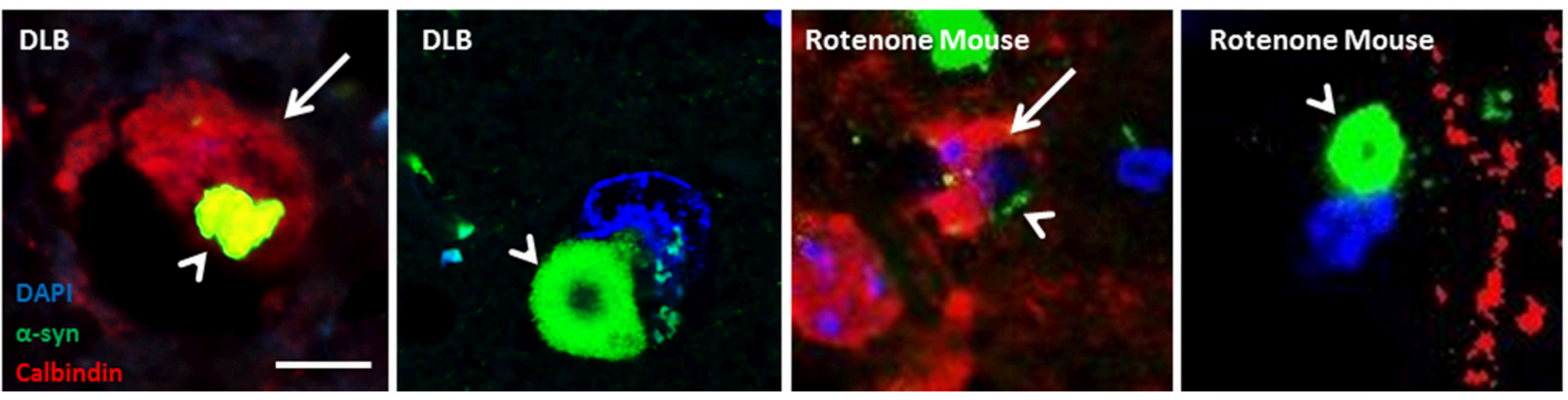

FIGURE 1 | (A) $\alpha$-Synuclein ( $\alpha$-syn) protein domain structure. KTK repeats in the N-terminus are involved in lipid interaction, the hydrophobic NAC domain is important for aggregation and the C-terminal Ca(II) binding site can increase the rate of oligomerization (Nielsen et al., 2001; Lowe et al., 2004). Parkinson's disease linked point mutations are indicated within the neurotransmitter vesicle binding domain. (B) Neuronal Calbindin-D28K (CB), inhibits $\alpha$-syn inclusion bodies in DLB and mouse model tissue (Rcom-H'cheo-Gauthier et al., 2016). (B1-2) Dementia with Lewy bodies immunofluorescence for $\alpha$-syn (green) and CB (red, arrow) showing rare, small cytoplasmic $\alpha$-syn aggregates (arrowhead) in a CB+ neuron and a typical, large perinuclear $\alpha$-syn inclusion body in a CB- neuron. (B3-4) Rotenone lesioned mouse (oxidative stress) model shows a similar pattern of large perinuclear $\alpha$-syn inclusion bodies that are absent from CB expressing neurons, with only small $\alpha$-syn puncta rarely detected in CB positive cells; scale bar $5 \mu \mathrm{m}$. 
found in PD-derived Lewy bodies (LBs) were pathogenic and had the capacity to initiate a PD-like pathological process. This included intracellular and presynaptic aggregation of pathological $\alpha$-syn species in various parts of the brain and progressive cell loss of dopaminergic neurons. Several metals have been implicated in the aggregation of $\alpha$-syn, including, iron, manganese, copper, and zinc (Santner and Uversky, 2010; McAllum and Finkelstein, 2016). However, this review will focus on calcium in alpha-synucleinopathies and its interaction with $\alpha$-syn.

\section{VOLTAGE-GATED Ca(II) CHANNELS IN NEURODEGENERATION}

Homeostatic $\mathrm{Ca}(\mathrm{II})$ regulation is essential to the health and functioning of cells. Although N-type voltage-gated $\mathrm{Ca}(\mathrm{II})$ channels $\left(\mathrm{Ca}_{\mathrm{v}}\right)$ are the primary regulators of $\mathrm{Ca}(\mathrm{II})$ influx and corresponding neurotransmitter release in neurons (Simms and Zamponi, 2014), various studies highlight the broader range of $\mathrm{Ca}(\mathrm{II})$ channels found throughout the CNS. There are three types of $\mathrm{Ca}_{\mathrm{v}}$ expressed in the brain, $\mathrm{Ca}_{\mathrm{v}} 1, \mathrm{Ca}_{\mathrm{v}} 2$, and $\mathrm{Ca}_{\mathrm{v}} 3$ (Catterall et al., 2005), comprising four $\mathrm{Ca}_{\mathrm{v}} 1$ subtypes (L-type configuration), three types of $\mathrm{Ca}_{\mathrm{v}} 2$ channels $(\mathrm{P} / \mathrm{Q}, \mathrm{N}$, and $\mathrm{R}$ configuration), with $\mathrm{Ca}_{\mathrm{V}} 2.1$ and $\mathrm{Ca}_{\mathrm{V}} 2.2$ responsible for neurotransmitter release, and the family of low-voltage activated T-type channels, $\mathrm{Ca}_{\mathrm{v}} 3.1, \mathrm{Ca}_{\mathrm{v}} 3.2$, and $\mathrm{Ca}_{\mathrm{v}} 3.3$ (Talley et al., 1999; Heady et al., 2001; Catterall et al., 2005). Inhibition of $\mathrm{Ca}_{v} 1,2.1$, and 2.2 channels have each been shown to decrease neuronal damage upon brain injury (Perez-Pinzon et al., 1997; Babu and Ramanathan, 2011; Kim et al., 2016), which also leads to increased $\alpha$-syn expression, $\alpha$-syn aggregation, and Parkinson's-like pathology (Acosta et al., 2015). $\mathrm{Ca}_{v} 3$ contribute to the pathogenesis of epilepsy (Chemin et al., 2001), and have also been reported in glial cells (Yunker et al., 2003). Bassoon, a neuronal zinc finger pre-synaptic scaffold protein shows increased expression in MSA cerebellum (Hashida et al., 1998). Interestingly, Bassoon increased $\mathrm{Ca}_{\mathrm{v}} 2.1$ expression, associated with a longer calcium transient, when over-expressed and decreased $\mathrm{Ca}_{\mathrm{v}} 2.1$ when knocked out in an epilepsy model (Davydova et al., 2014; Ivanova et al., 2015). Moreover, pathological $\alpha$-syn species may mediate calcium entry and thus both further promote calcium-dependent $\alpha$-syn aggregation and directly lead to calcium-dependent cytotoxicity (Angelova and Abramov, 2016). Wildburger et al. (2009) investigated the neuroprotective properties of the $\mathrm{Ca}$ (II) channel blocker, trimethadione (TMO), in cultured hippocampal and cortical neurons from $\mathrm{C} 57 \mathrm{BL} / 6$ and $\alpha 1 \mathrm{H}^{-/-}$mice, showing a significant decrease in cell death following TMO treatment (Wildburger et al., 2009). Moreover, Follett et al. (2013) showed that SH-SY5Y cells subjected to membrane depolarization by potassium resulted in $\mathrm{Ca}$ (II) influx and $\alpha$-syn-positive cytoplasmic aggregates that could be blocked by TMO pre-treatment. Furthermore, Danish subjects taking dihydropyridine L-type calcium channel blockers between 1995 and 2006 were 27\% less likely to develop PD (Ritz et al., 2010; Pasternak et al., 2012). Following this, a Phase II tolerability trial in early stage PD patients was conducted and found that isradipine was well-tolerated (Parkinson Study Group, 2013).

\section{Ca(II) REGULATION IN AGEING AND NEURODEGENERATION}

Regulation of calcium homeostasis requires a complex interplay between the cytoplasmic channels/pumps and intracellular $\mathrm{Ca}$ (II) stores, such as the mitochondria and endoplasmic reticulum (ER), and may be affected by age (Toescu and Verkhratsky, 2007). It has been established that resting intracellular $\mathrm{Ca}(\mathrm{II})$ levels remain the same despite the age of the neuron. However, the return time to resting levels is significantly increased in aged neurons after a stimulus. Aged neurons also exhibit a decreased capacity to recover from $\mathrm{Ca}$ (II) stimulus through uptake into the intracellular $\mathrm{Ca}$ (II) stores with a decline in sarco/endoplasmic reticulum $\mathrm{Ca}$ (II)-ATPase (SERCA) function (Pottorf et al., 2000). Moreover, $\mathrm{Ca}$ (II) pumping into the extracellular space via the plasma membrane $\mathrm{Ca}(\mathrm{II})$ ATPase (PMCA) has been shown to be impaired in aged neurons (Michaelis et al., 1996). The calcium buffering capacity of neurons was also shown to be decreased in aged neurons and some studies have shown that after stimulation, the concentration of $\mathrm{Ca}$ (II) may be decreased, but the recovery time back to resting levels is dramatically increased (Duckles et al., 1996). Calbindin D28K (CB), calretinin (CR), and parvalbumin (PV) are three cytosolic $\mathrm{Ca}(\mathrm{II})$ buffering proteins (CBP) that are capable of $\mathrm{Ca}(\mathrm{II})$ buffering in neurons and belong to the EF-hand protein family. The other CBP family is the annexin family and is characterized by proteins that bind $\mathrm{Ca}(\mathrm{II})$ in the presence of phospholipids-containing membranes (Andressen et al., 1993). The EF-hand proteins may function either as $\mathrm{Ca}(\mathrm{II})$ buffers, decreasing the free cytoplasmic concentration, or as triggers starting a cascade of responses (Dalgarno et al., 1984). The ubiquitous trigger protein calmodulin activates at least 20 different enzymes, while PV, $\mathrm{CB}$, and $\mathrm{CR}$, are more passive buffers decreasing the amplitude of $\mathrm{Ca}(\mathrm{II})$ signals. In a human study conducted by $\mathrm{Bu}$ et al. (2003), a decrease was found in both CR and CB in aged compared to young cortical neurons, but no difference in PV positive neurons. Yamada et al. (1990) found that dopaminergic neurons of the Substantia nigra pars compacta $(\mathrm{SnPc})$ that were high in $\mathrm{CB}$ were preferentially spared in control brain sections compared with PD patients. The importance of these proteins has also been implicated by German et al. (1992) who studied the brains of human patients with PD, MPTP monkey or in C57BL/6. They found that in both idiopathic PD and in the above models, neurons that contained $\mathrm{CB}$ were spared while neurons in CB-negative (CB-) regions were lost. Gaspar et al. (1994) found that dopaminergic neurons expressing $\mathrm{CB}$ were spared from loss in a mouse model with Parkinsonian-like pathological features. Tsuboi et al. (2000) and Kim et al. (2000) found that $\mathrm{CR}$ expression in dopaminergic neurons of the SnPc were more protected against 6-hydroxydopamine (Kim et al., 2000; Tsuboi et al., 2000). Moreover, a recent study has described the overrepresentation of $\mathrm{CB}$-positive $(\mathrm{CB}+)$ neurons in $\mathrm{DLB}$, and the almost complete exclusion of $\alpha$-syn aggregates in $\mathrm{CB}+$ neurons. 
This study draws the same conclusions in a rotenone (oxidative stress) mouse model of $\alpha$-synucleopathy (Rcom-H'cheo-Gauthier et al., 2016). In both DLB and the mouse model, occasional neurons with low CB expression showed small $\alpha$-syn aggregates, but large perinuclear inclusion bodies were only detected in CBcells (Figure 1B; Rcom-H'cheo-Gauthier et al., 2016).

\section{INCREASED INTRACELLULAR Ca(II) INDUCES $\alpha$-SYNUCLEIN OLIGOMERISATION}

Nielsen et al. (2001) first demonstrated that Ca(II) binding to $\alpha$ syn regulates ligand binding and oligomerization. Subsequently, Lowe et al. (2004) found that calcium promoted $\alpha$-syn annular oligomer formation that required the C-terminal calcium binding site (Figure 1A). The $\alpha$-syn $C$ terminus contains a sequence of six negatively charged acidic amino acids similar to an EF-hand-like motif (Zhou et al., 2006), although more studies are required to precisely delineate the calcium binding residues. More recent studies have shown that by increasing free intracellular $\mathrm{Ca}(\mathrm{II})$ concentration thapsigargin or $\mathrm{Ca}(\mathrm{II})$ ionophore chemical treatments caused a significant increase in the proportion of cells bearing microscopically-visible $\alpha$ syn aggregates. It was also demonstrated that co-treatment with intracellular $\mathrm{Ca}(\mathrm{II})$ chelator, suppressed the aggregation, indicating that $\alpha$-syn aggregation was induced by raised intracellular free $\mathrm{Ca}(\mathrm{II})$ directly, although a possible role for calpain protease activation could not be excluded. Moreover, supporting studies with recombinant $\alpha$-syn indicated that direct binding of $\mathrm{Ca}(\mathrm{II})$ ion to $\alpha$-syn promoted rapid oligomer formation in vitro (Nath et al., 2011). More recently, Follett et al. (2013) demonstrated that depolarization of the plasma membrane resulted in raised intracellular free $\mathrm{Ca}$ (II) and $\alpha$-syn aggregation triggering the formation of large LB-like perinuclear $\alpha$-syn inclusion bodies after $48 \mathrm{~h}$ that could be inhibited both by $\mathrm{Ca}$ (II) chelation and calcium channel blockade (Follett et al., 2013). Moreover, Chan et al. (2007) assessing Ca(II) blockade using brain slices from a MPTP mouse model of PD determined that the L-type $\mathrm{Ca}_{v} 1.3 \mathrm{Ca}$ (II) channel inhibitor, Isradipine, a drug used to treat high blood pressure, could recover dopaminergic neural activity. Furthermore, Singh et al. (2016) also used an L-type calcium channel blocker, nimodipine, in the same model and observed reduced loss of TH positive neurons and reduced reactive oxygen species (ROS) production in the striatal mitochondria.

\section{OXIDATIVE STRESS AND $\alpha$-SYNUCLEIN OLIGOMERIZATION}

Another potential target for $\alpha$-synucleinopathy therapeutics could be to target oxidative stress in the brain. There is evidence that oxidative stress is increased in the normal aged brain, however the level of oxidative stress is greatly increased in patients with neurodegenerative diseases (Sims-Robinson et al., 2013). Thus, WT $\alpha$-syn has been shown to induce mitochondrial NO when it is associated with mitochondria (Parihar et al.,
2008). This indicates that not only will normal increases in oxidative stress cause aggregation but that aggregation of $\alpha$ syn also induces more oxidative stress within the cell forming a positive feedback loop. Moreover, other research shows that $\alpha$-syn protects cells from oxidative stress by deactivating the c-jun $\mathrm{N}$-terminal kinase (JNK) pathway, although this data was from cells challenged with exogenous $\mathrm{H}_{2} \mathrm{O}_{2}$ (Hashimoto et al., 2002). The combination of oxidative stress and $\alpha$-syn expression has been used to generate a model of MSA in mice, whereby the over-expression of $\alpha$-syn in glial cells is combined with 3-nitropropionic acid. Treatment to induce mitochondrial oxidative stress was sufficient to induce MSA like pathology (Ubhi et al., 2009). Moreover, Kume et al. (2012) found urinary 8-OHdG levels were significantly higher in DLB cases compared to controls, indicating systemically increased oxidative stress. Oxidative stress in aging primates originates primarily from mitochondrial complexes I and III of the electron transport chain which leads to greater mitochondrial DNA damage compared to nuclear DNA (Castro Mdel et al., 2012). Indeed, widespread mitochondrial DNA damage occurs at early stages of DLB (Lin et al., 2012). Moreover, $\alpha$-syn oligomers promoted $\mathrm{Ca}(\mathrm{II})$-induced mitochondrial dysfunction (Luth et al., 2014) and oxidative stress characterized by $\alpha$-syn lipoxidation precedes the formation of $\alpha$-syn aggregates and the development of neocortical LB pathology in DLB (Dalfo and Ferrer, 2008). Furthermore, Quilty et al. (2006) showed that when mouse primary neocortical cells were incubated in the absence of antioxidants, mild oxidative stress caused $\alpha$-syn accumulation in a subset of neurons. Indeed, recent studies have found the oxidized form of the endogenous oxidative stress sensor, DJ1 , progressively increased in the later stages of PD and more highly oxidized forms were likely present in DLB (Saito et al., 2014). Furthermore, it has been demonstrated that $\mathrm{Ca}$ (II) influx can interact with $\alpha$-syn to mediate increased oxidative stress (Dryanovski et al., 2013; Surmeier et al., 2016). Indeed, the combination of oxidative stress and raised intracellular free $\mathrm{Ca}(\mathrm{II})$ showed a synergistic effect on $\alpha$-syn aggregation (Goodwin et al., 2013). More recently, $\alpha$-syn aggregation was studied using an oxidative stress mouse model where unilateral lesion was performed using the mitochondrial complex I inhibitor, rotenone. The results showed an increase in $\alpha$-syn aggregates in the lesioned hemisphere, compared to sham or unlesioned, especially in aged animals, combined with an exclusion of $\alpha$-syn aggregates from $\mathrm{CB}$-expressing neurons, further implicating a cooperative interaction between calcium buffering and oxidative stress (Rcom-H'cheo-Gauthier et al., 2016).

\section{$\alpha$-SYNUCLEIN AGGREGATION, RAISED $\mathrm{Ca}(I I)$, AND OXIDATIVE STRESS}

Hettiarachchi et al. (2009) demonstrated that elevated levels of intracellular $\alpha$-syn elevated levels of intracellular $\mathrm{Ca}(\mathrm{II})$, although reduced $\mathrm{Ca}(\mathrm{II})$ was observed in primary neurons overexpressing $\alpha$-syn when treated with manganese (Dučić et al., 2015). Furthermore, secreted $\alpha$-syn induced an increase in capacitive $\mathrm{Ca}$ (II) entry in differentiated SH-SY5Y cells (Melachroinou et al., 


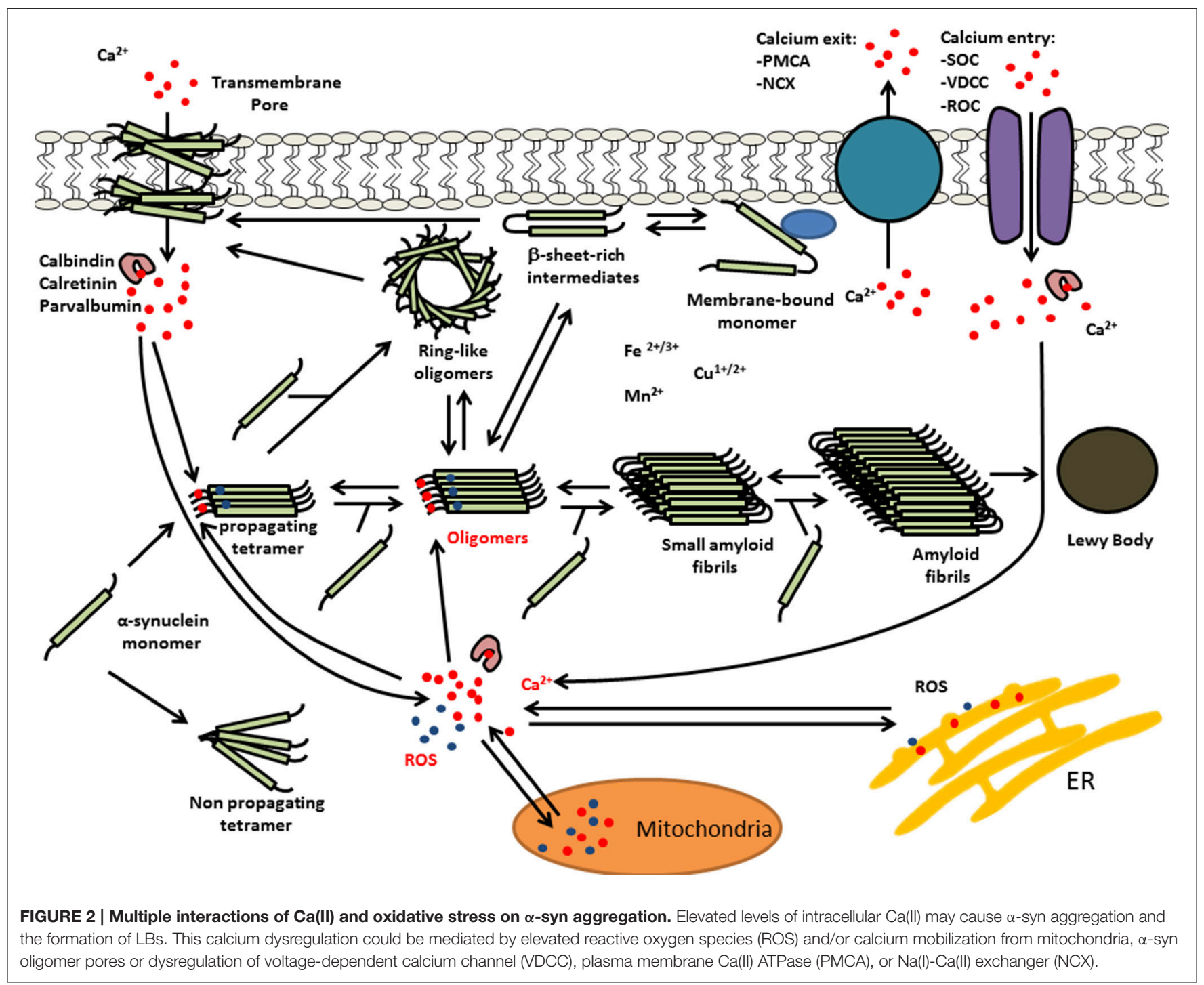

2013). Transmembrane entry of $\mathrm{Ca}(\mathrm{II})$ or other cations may be via $\alpha$-syn pore-like oligomers (Pountney et al., 2005; Mironov, 2015) and can mediate cytotoxicity (Angelova et al., 2016). Transgenic mice over-expressing human WT $\alpha$-syn showed that $\alpha$-syn transgenic mice exhibited augmented, long-lasting $\mathrm{Ca}(\mathrm{II})$ transients characterized by considerable deviation from the exponential decay. Furthermore control and $\alpha$-syn knock out groups demonstrated low percentages of neurons with $\mathrm{Ca}$ (II) abnormalities whereas the $\alpha$-syn transgenic group showed $\mathrm{Ca}$ (II) response alteration, suggesting these alterations are related to $\alpha$-syn expression (Reznichenko et al., 2012; Mironov, 2015). Furthermore, Navarria et al. (2015) showed that overexpression of $\alpha$-syn reduced NMDAR-mediated $\mathrm{Ca}$ (II) influx.

Cali et al. (2012) observed significantly greater levels of mitochondrial $\mathrm{Ca}(\mathrm{II})$ in $\alpha$-syn treated cells compared to control cells. In SH-SY5Y and HeLa cells, ER-mitochondria interactions and increased mitochondrial $\mathrm{Ca}(\mathrm{II})$ were enhanced by overexpressed $\alpha$-syn and increased mitochondrial $\mathrm{Ca}$ (II) transient. Moreover, treatment with native $\alpha$-syn increased $\mathrm{Ca}(\mathrm{II})$ entry in primary rat cortical neurons and induced mitochondrial $\mathrm{Ca}(\mathrm{II})$ uptake. Dryanovski et al. (2013) found that in dopaminergic neurons bearing inclusions, ROS levels in the mitochondria were greater in the soma and proximal dendrites than in neurons not bearing any inclusions. Treatment with isradipine significantly reduced the ROS levels in $\mathrm{CB}-$ dopaminergic neurons when compared to $\mathrm{CB}+$ dopaminergic neurons, suggesting ROS production in the cytosol is triggered by the formation of $\alpha$-syn inclusions. Buttner et al. (2013) established that $\alpha$-syn leads to elevated cytosolic $\mathrm{Ca}$ (II) in yeast that coincides with an increase in oxidative stress. This suggests that the formation of $\alpha$-syn aggregates triggers an increase in mitochondrial $\mathrm{Ca}$ (II) transient and then leads to oxidative stress. WT $\alpha$-syn also displayed the capacity to induce mitochondrial NO when associated with mitochondria (Parihar et al., 2008) and oxidative stress induced by $\mathrm{Ca}(\mathrm{II})$ influx was worsened in a DJ-1 mutant mouse PD model (Goldberg et al., 2012). Thus, an 
increase in oxidative stress can cause $\alpha$-syn aggregation and that aggregation can also induce further oxidative stress within the cell forming a positive feedback loop. Though, this contradicts other research by Hashimoto et al. (2002) which shows that $\alpha$ syn protects cells from oxidative stress by inactivating the JNK pathway. More recently, the antioxidant capacity of SH-SY5Y cells was shown to be decreased by changes in SOD1 and SOD2 enzyme activity and decreased gluthathione levels following overexpression of $\alpha$-syn (Perfeito et al., 2016). Koch et al. (2016) also found that $\alpha$-syn fibrils increase SOD1 aggregation in vitro and in vivo.

Recent findings indicate that oxidative stress and increased intracellular free $\mathrm{Ca}$ (II) synergistically increased the number of $\alpha$ syn-positive aggregates (Goodwin et al., 2013). Moreover, in vitro experiments demonstrated that $\mathrm{Ca}(\mathrm{II})$ binding alone was able to induce non-stable $\alpha$-syn aggregates, whereas, co-treatments with $\mathrm{Ca}(\mathrm{II})$ and oxidant resulted in the formation of larger, stable aggregates. Furthermore, kinetic experiments of $\alpha$-syn aggregate formation by Nath et al. (2010) were consistent with an auto-catalytic mechanism. Thus, $\mathrm{Ca}$ (II)/oxidation stabilized $\alpha$-syn aggregates could in turn serve to increase nucleation centers in disease. This is supported by work performed by Krishnan et al. (2003) that show that oxidatively di-tyrosine cross linked $\alpha$-syn dimers were the rate limiting step in the fibrillation process in forming nucleation centers. Moreover, $\mathrm{Ca}(\mathrm{II})$ influx into neurons can induce oxidative stress that may in turn result

\section{REFERENCES}

Acosta, S. A., Tajiri, N., de la Pena, I., Bastawrous, M., Sanberg, P. R., Kaneko, Y., et al. (2015). Alpha-synuclein as a pathological link between chronic traumatic brain injury and Parkinson's disease. J. Cell. Physiol. 230, 1024-1032. doi: $10.1002 / j c p .24830$

Andressen, C., Blümcke, I., and Celio, M. R. (1993). Calcium-binding proteins: selective markers of nerve cells. Cell Tissue Res. 271, 181-208. doi: 10.1007/BF00318606

Angelova, P. R., and Abramov, A. Y. (2016). Alpha-synuclein and beta-amyloid-different targets, same players: calcium, free radicals and mitochondria in the mechanism of neurodegeneration. Biochem. Biophys. Res. Commun. doi: 10.1016/j.bbrc.2016.07.103. [Epub ahead of print].

Angelova, P. R., Ludtmann, M. H., Horrocks, M. H., Negoda, A., Cremades, N., Klenerman, D., et al. (2016). $\mathrm{Ca}^{2+}$ is a key factor in $\alpha$-synuclein-induced neurotoxicity. J. Cell Sci. 129, 1792-1801. doi: 10.1242/jcs.180737

Babu, C. S., and Ramanathan, M. (2011). Post-ischemic administration of nimodipine following focal cerebral ischemic-reperfusion injury in rats alleviated excitotoxicity, neurobehavioural alterations and partially the bioenergetics. Int. J. Dev. Neurosci. 29, 93-105. doi: 10.1016/j.ijdevneu.2010. 08.001

Bu, J., Sathyendra, V., Nagykery, N., and Geula, C. (2003). Age-related changes in calbindin-D28k, calretinin, and parvalbumin-immunoreactive neurons in the human cerebral cortex. Exp. Neurol. 182, 220-231. doi: 10.1016/S0014-4886(03)00094-3

Buttner, S., Faes, L., Reichelt, W. N., Broeskamp, F., Habernig, L., Benke, S., et al. (2013). The $\mathrm{Ca}^{2+} / \mathrm{Mn}^{2+}$ ion-pump PMR1 links elevation of cytosolic $\mathrm{Ca}^{2+}$ levels to alpha-synuclein toxicity in Parkinson's disease models. Cell Death Differ. 20, 465-477. doi: 10.1038/cdd.2012.142

Cali, T., Ottolini, D., Negro, A., and Brini, M. (2012). alpha-Synuclein controls mitochondrial calcium homeostasis by enhancing endoplasmic reticulum-mitochondria interactions. J. Biol. Chem. 287, 17914-17929. doi: 10.1074/jbc.M111.302794 in further $\alpha$-syn aggregation. Figure 2 summarizes the potential synergies between raised calcium levels, oxidative stress, and $\alpha$-syn aggregation.

\section{CONCLUSION: CHALLENGES FOR FUTURE THERAPEUTICS}

Calcium channel antagonists are currently undergoing clinical trials for PD therapy, however many of these drugs may display undesirable features when used chronically. Modulating neuronal calcium homoeostasis via endogenous CBP or through differential calcium channel recruitment could offer efficient alternatives.

\section{AUTHOR CONTRIBUTIONS}

DP: Research group leader coordinated writing, editing of text and figures. AR: lead author contributed majority of text. SO: contributed some text. AM: reviewing co-author.

\section{ACKNOWLEDGMENTS}

Supported by Griffith University, Australian Research Council and Menzies Health Institute Queensland and Parkinson's Queensland.
Castro Mdel, R., Suarez, E., Kraiselburd, E., Isidro, A., Paz, J., Ferder, L., et al. (2012). Aging increases mitochondrial DNA damage and oxidative stress in liver of rhesus monkeys. Exp. Gerontol. 47, 29-37. doi: 10.1016/j.exger.2011.10.002

Catterall, W. A., Perez-Reyes, E., Snutch, T. P., and Striessnig, J. (2005). International union of pharmacology. XLVIII. Nomenclature and structurefunction relationships of voltage-gated calcium channels. Pharmacol. Rev. 57, 411-425. doi: 10.1124/pr.57.4.5

Chan, C. S., Guzman, J. N., Ilijic, E., Mercer, J. N., Rick, C., Tkatch, T., et al. (2007). 'Rejuvenation' protects neurons in mouse models of Parkinson's disease. Nature 447, 1081-1086. doi: 10.1038/nature05865

Chartier-Harlin, M. C., Kachergus, J., Roumier, C., Mouroux, V., Douay, X., Lincoln, S., et al. (2004). alpha-synuclein locus duplication as a cause of familial Parkinson's disease. Lancet 364, 1167-1169. doi: 10.1016/S0140-6736(04)17103-1

Chemin, J., Monteil, A., Perez-Reyes, E., Nargeot, J., and Lory, P. (2001). Direct inhibition of T-type calcium channels by the endogenous cannabinoid anandamide. EMBO J. 20, 7033-7040. doi: 10.1093/emboj/20. 24.7033

Clayton, D. F., and George, J. M. (1999). Synucleins in synaptic plasticity and neurodegenerative disorders. J. Neurosci. Res. 58, 120-129. doi: 10.1002/(SICI)1097-4547(19991001)58:1 < 120::AID-JNR12>3.0.CO;2-E

Conway, K. A., Harper, J. D., and Lansbury, P. T. (1998). Accelerated in vitro fibril formation by a mutant alpha-synuclein linked to early-onset Parkinson disease. Nat. Med. 4, 1318-1320. doi: 10.1038/3311

Conway, K. A., Lee, S. J., Rochet, J. C., Ding, T. T., Williamson, R. E., and Lansbury, P. T. Jr. (2000). Acceleration of oligomerization, not fibrillization, is a shared property of both alpha-synuclein mutations linked to early-onset Parkinson's disease: implications for pathogenesis and therapy. Proc. Natl. Acad. Sci. U.S.A. 97, 571-576. doi: 10.1073/pnas.97.2.571

Dalfo, E., and Ferrer, I. (2008). Early alpha-synuclein lipoxidation in neocortex in Lewy body diseases. Neurobiol. Aging 29, 408-417. doi: 10.1016/j.neurobiolaging.2006.10.022 
Dalgarno, D., Klevit, R. E., Levine, B. A., and Williams, R. J. P. (1984). The calcium receptor and trigger. Trends Pharmacol. Sci. 5, 266-271. doi: 10.1016/0165-6147(84)90442-5

Davydova, D., Marini, C., King, C., Klueva, J., Bischof, F., Romorini, S., et al. (2014). Bassoon specifically controls presynaptic P/Q-type $\mathrm{Ca}(2+)$ channels via RIM-binding protein. Neuron 82, 181-194. doi: 10.1016/j.neuron.2014.02.012

DeWitt, D. C., and Rhoades, E. (2013). $\alpha$-Synuclein can inhibit SNARE-mediated vesicle fusion through direct interactions with lipid bilayers. Biochemistry 52, 2385-2387. doi: 10.1021/bi400236

Dryanovski, D. I., Guzman, J. N., Xie, Z., Galteri, D. J., Volpicelli-Daley, L. A., Lee, V. M., et al. (2013). Calcium entry and alpha-synuclein inclusions elevate dendritic mitochondrial oxidant stress in dopaminergic neurons. J. Neurosci. 33, 10154-10164. doi: 10.1523/JNEUROSCI.5311-12.2013

Dučić, T., Carboni, E., Lai, B., Chen, S., Michalke, B., Lázaro, D. F., et al. (2015). Alpha-synuclein regulates neuronal levels of manganese and calcium. ACS Chem. Neurosci. 6, 1769-1779. doi: 10.1021/acschemneuro.5b00093

Duckles, S. P., Tsai, H., and Buchholz, J. N. (1996). Evidence for decline in intracellular calcium buffering in adrenergic nerves of aged rats. Life Sci. 58, 2029-2035. doi: 10.1016/0024-3205(96)00194-4

Eschbach, J., and Danzer, K. M. (2014). alpha-Synuclein in Parkinson's disease: pathogenic function and translation into animal models. Neurodegener. Dis. 14, 1-17. doi: 10.1159/000354615

Follett, J., Darlow, B., Wong, M. B., Goodwin, J., and Pountney, D. L. (2013). Potassium depolarization and raised calcium induces alpha-synuclein aggregates. Neurotox. Res. 23, 378-392. doi: 10.1007/s12640-012-9366-Z

Gaspar, P., Ben Jelloun, N., and Febvret, A. (1994). Sparing of the dopaminergic neurons containing calbindin-D28k and of the dopaminergic mesocortical projections in weaver mutant mice. Neuroscience 61, 293-305. doi: 10.1016/0306-4522(94)90232-1

German, D. C., Manaye, K. F., Sonsalla, P. K., and Brooks, B. A. (1992). Midbrain dopaminergic cell loss in Parkinson's disease and MPTP-induced parkinsonism: sparing of calbindin-D28k-containing cells. Ann. N. Y. Acad. Sci. 648, 42-62. doi: 10.1111/j.1749-6632.1992.tb24523.x

Goedert, M., Spillantini, M. G., Del Tredici, K., and Braak, H. (2013). 100 years of Lewy pathology. Nat. Rev. Neurol. 9, 13-24. doi: 10.1038/nrneurol.2012.242

Goldberg, J. A., Guzman, J. N., Estep, C. M., Ilijic, E., Kondapalli, J., SanchezPadilla, J., et al. (2012). Calcium entry induces mitochondrial oxidant stress in vagal neurons at risk in Parkinson's disease. Nat. Neurosci. 15, 1414-1421. doi: 10.1038/nn.3209

Goodwin, J., Nath, S., Engelborghs, Y., and Pountney, D. L. (2013). Raised calcium and oxidative stress cooperatively promote alpha-synuclein aggregate formation. Neurochem. Int. 62, 703-711. doi: 10.1016/j.neuint.2012.11.004

Hashida, H., Goto, J., Zhao, N., Takahashi, N., Hirai, M., Kanazawa, I., et al. (1998). Cloning and mapping of ZNF231, a novel brain-specific gene encoding neuronal double zinc finger protein whose expression is enhanced in a neurodegenerative disorder, multiple system atrophy (MSA). Genomics 54, 50-58. doi: 10.1006/geno.1998.5516

Hashimoto, M., Hsu, L. J., Rockenstein, E., Takenouchi, T., Mallory, M., and Masliah, E. (2002). alpha-Synuclein protects against oxidative stress via inactivation of the c-Jun N-terminal kinase stress-signaling pathway in neuronal cells. J. Biol. Chem. 277, 11465-11472. doi: 10.1074/jbc.M111428200

Heady, T. N., Gomora, J. C., Macdonald, T. L., and Perez-Reyes, E. (2001). Molecular pharmacology of T-type $\mathrm{Ca}^{2+}$ channels. Jpn. J. Pharmacol. 85, 339-350. doi: 10.1254/jjp.85.339

Hettiarachchi, N. T., Parker, A., Dallas, M. L., Pennington, K., Hung, C. C., Pearson, H. A., et al. (2009). alpha-Synuclein modulation of $\mathrm{Ca}^{2+}$ signaling in human neuroblastoma (SH-SY5Y) cells. J. Neurochem. 111, 1192-1201. doi: 10.1111/j.1471-4159.2009.06411.x

Ibanez, P., Bonnet, A. M., Debarges, B., Lohmann, E., Tison, F., Pollak, P., et al. (2004). Causal relation between alpha-synuclein gene duplication and familial Parkinson's disease. Lancet 364, 1169-1171. doi: 10.1016/S0140-6736(04)17104-3

Ivanova, D., Dirks, A., Montenegro-Venegas, C., Schone, C., Altrock, W. D., Marini, C., et al. (2015). Synaptic activity controls localization and function of CtBP1 via binding to Bassoon and Piccolo. EMBO J. 34, 1056-1077. doi: 10.15252/embj.201488796

Iwai, A., Masliah, E., Yoshimoto, M., Ge, N., Flanagan, L., de Silva, H. A., et al. (1995). The precursor protein of non-A beta component of Alzheimer's disease amyloid is a presynaptic protein of the central nervous system. Neuron 14, 467-475. doi: 10.1016/0896-6273(95)90302-X

Kanda, S., Bishop, J. F., Eglitis, M. A., Yang, Y., and Mouradian, M. M. (2000). Enhanced vulnerability to oxidative stress by alpha-synuclein mutations and C-terminal truncation. Neuroscience 97, 279-284. doi: 10.1016/S0306-4522(00)00077-4

Kim, B. G., Shin, D. H., Jeon, G. S., Seo, J. H., Kim, Y. W., Jeon, B. S., et al. (2000). Relative sparing of calretinin containing neurons in the substantia nigra of 6-OHDA treated rat parkinsonian model. Brain Res. 855, 162-165. doi: 10.1016/S0006-8993(99)02374-4

Kim, T. Y., Yoshimoto, T., Aoyama, Y., Niimi, K., and Takahashi, E. (2016). Analysis of the protective effects of a neuronal Cav2.1 calcium channel in brain injury. Neuroscience 313, 110-121. doi: 10.1016/j.neuroscience.2015.11.035

Koch, Y., Helferich, A. M., Steinacker, P., Oeckl, P., Walther, P., Weishaupt, J. H., et al. (2016). Aggregated $\alpha$-synuclein increases SOD1 oligomerization in a mouse model of amyotrophic lateral sclerosis. Am. J. Pathol. 186, 2152-2161. doi: 10.1016/j.ajpath.2016.04.008

Krishnan, S., Chi, E. Y., Wood, S. J., Kendrick, B. S., Li, C., Garzon-Rodriguez, W., et al. (2003). Oxidative dimer formation is the critical rate-limiting step for Parkinson's disease alpha-synuclein fibrillogenesis. Biochemistry 42, 829-837. doi: 10.1021/bi026528t

Kruger, R., Kuhn, W., Muller, T., Woitalla, D., Graeber, M., Kosel, S., et al. (1998). Ala30Pro mutation in the gene encoding alpha-synuclein in Parkinson's disease. Nat. Genet. 18, 106-108. doi: 10.1038/ng0298-106

Kume, K., Kikukawa, M., Hanyu, H., Takata, Y., Umahara, T., Sakurai, H., et al. (2012). Telomere length shortening in patients with dementia with Lewy bodies. Eur. J. Neurol. 19, 905-910. doi: 10.1111/j.1468-1331.2011.03655.x

Lesage, S., Anheim, M., Letournel, F., Bousset, L., Honore, A., Rozas, N., et al. (2013). G51D alpha-synuclein mutation causes a novel parkinsonianpyramidal syndrome. Ann. Neurol. 73, 459-471. doi: 10.1002/ana.23894

Lin, M. T., Cantuti-Castelvetri, I., Zheng, K., Jackson, K. E., Tan, Y. B., Arzberger, T., et al. (2012). Somatic mitochondrial DNA mutations in early Parkinson and incidental Lewy body disease. Ann. Neurol. 71, 850-854. doi: 10.1002/ana.23568

Lowe, R., Pountney, D. L., Jensen, P. H., Gai, W. P., and Voelcker, N. H. (2004). Calcium(II) selectively induces alpha-synuclein annular oligomers via interaction with the C-terminal domain. Protein Sci. 13, 3245-3252. doi: $10.1110 /$ ps.04879704

Luth, E. S., Stavrovskaya, I. G., Bartels, T., Kristal, B. S., and Selkoe, D. J. (2014). Soluble, prefibrillar $\alpha$-synuclein oligomers promote complex I-dependent, $\mathrm{Ca}^{2+}$-induced mitochondrial dysfunction. J. Biol. Chem. 289, 21490-21507. doi: $10.1074 /$ jbc.m113.545749

Maroteaux, L., Campanelli, J. T., and Scheller, R. H. (1988). Synuclein: a neuronspecific protein localized to the nucleus and presynaptic nerve terminal. J. Neurosci. 8, 2804-2815.

McAllum, E. J., and Finkelstein, D. I. (2016). Metals in Alzheimer's and Parkinson's disease: relevance to dementia with lewy bodies. J. Mol. Neurosci. 60, 279-288. doi: 10.1007/s12031-016-0809-5

Melachroinou, K., Xilouri, M., Emmanouilidou, E., Masgrau, R., Papazafiri, P., Stefanis, L., et al. (2013). Deregulation of calcium homeostasis mediates secreted alpha-synuclein-induced neurotoxicity. Neurobiol. Aging 34, 2853-2865. doi: 10.1016/j.neurobiolaging.2013.06.006

Michaelis, M. L., Bigelow, D. J., Schoneich, C., Williams, T. D., Ramonda, L., Yin, D., et al. (1996). Decreased plasma membrane calcium transport activity in aging brain. Life Sci. 59, 405-412. doi: 10.1016/0024-3205(96)00319-0

Mironov, S. L. (2015). $\alpha$-Synuclein forms non-selective cation channels and stimulates ATP-sensitive potassium channels in hippocampal neurons. J. Physiol. 593(Pt 1), 145-159. doi: 10.1113/jphysiol.2014.280974

Narhi, L., Wood, S. J., Steavenson, S., Jiang, Y., Wu, G. M., Anafi, D., et al. (1999). Both familial Parkinson's disease mutations accelerate alphasynuclein aggregation. J. Biol. Chem. 274, 9843-9846. doi: 10.1074/jbc.274. 14.9843

Nath, S., Goodwin, J., Engelborghs, Y., and Pountney, D. L. (2011). Raised calcium promotes alpha-synuclein aggregate formation. Mol. Cell. Neurosci. 46, 516-526. doi: 10.1016/j.mcn.2010.12.004

Nath, S., Meuvis, J., Hendrix, J., Carl, S. A., and Engelborghs, Y. (2010). Early aggregation steps in $\alpha$-synuclein as measured by FCS and FRET: evidence for a contagious conformational change. Biophys. J. 98, 1302-1311. doi: 10.1016/j. bpj.2009.12.4290 
Navarria, L., Zaltieri, M., Longhena, F., Spillantini, M. G., Missale, C., Spano, P., et al. (2015). Alpha-synuclein modulates NR2B-containing NMDA receptors and decreases their levels after rotenone exposure. Neurochem. Int. 85-86, 14-23. doi: 10.1016/j.neuint.2015.03.008

Nielsen, M. S., Vorum, H., Lindersson, E., and Jensen, P. H. (2001). Ca ${ }^{2+}$ binding to alpha-synuclein regulates ligand binding and oligomerization. J. Biol. Chem. 276, 22680-22684. doi: 10.1074/jbc.M101181200

Parihar, M. S., Parihar, A., Fujita, M., Hashimoto, M., and Ghafourifar, P. (2008). Mitochondrial association of alpha-synuclein causes oxidative stress. Cell. Mol. Life Sci. 65, 1272-1284. doi: 10.1007/s00018-008-7589-1

Parkinson Study Group (2013). Phase II safety, tolerability, and dose selection study of isradipine as a potential disease-modifying intervention in early Parkinson's disease (STEADY-PD). Mov. Disord. 28, 1823-1831. doi: $10.1002 / \mathrm{mds} .25639$

Pasanen, P., Myllykangas, L., Siitonen, M., Raunio, A., Kaakkola, S., Lyytinen, J., et al. (2014). A novel $\alpha$-synuclein mutation A53E associated with atypical multiple system atrophy and Parkinson's disease-type pathology. Neurobiol. Aging 35, 2180.e1-e5. doi: 10.1016/j.neurobiolaging.2014.03.024

Pasternak, B., Svanstrom, H., Nielsen, N. M., Fugger, L., Melbye, M., and Hviid, A. (2012). Use of calcium channel blockers and Parkinson's disease. Am. J. Epidemiol. 175, 627-635. doi: 10.1093/aje/kwr362

Perez-Pinzon, M. A., Yenari, M. A., Sun, G. H., Kunis, D. M., and Steinberg, G. K. (1997). SNX-111, a novel, presynaptic N-type calcium channel antagonist, is neuroprotective against focal cerebral ischemia in rabbits. J. Neurol. Sci. 153, 25-31. doi: 10.1016/S0022-510X(97)00196-2

Perfeito, R., Ribeiro, M., and Rego, A. C. (2016). Alpha-synuclein-induced oxidative stress correlates with altered superoxide dismutase and glutathione synthesis in human neuroblastoma SH-SY5Y cells. Arch Toxicol. doi: 10.1007/s00204-016-1788-6. [Epub ahead of print].

Polymeropoulos, M. H., Lavedan, C., Leroy, E., Ide, S. E., Dehejia, A., Dutra, A., et al. (1997). Mutation in the alpha-synuclein gene identified in families with Parkinson's disease. Science 276, 2045-2047. doi: $10.1126 /$ science. 276.5321 .2045

Pottorf, W. J., Duckles, S. P., and Buchholz, J. N. (2000). SERCA function declines with age in adrenergic nerves from the superior cervical ganglion. J. Auton. Pharmacol. 20, 281-290. doi: 10.1046/j.1365-2680.2000.00194.x

Pountney, D. L., Voelcker, N. H., and Gai, W. P. (2005). Annular alpha-synuclein oligomers are potentially toxic agents in alpha-synucleinopathy. Neurotox. Res. 7, 59-67. doi: 10.1007/BF03033776

Proukakis, C., Dudzik, C. G., Brier, T., MacKay, D. S., Cooper, J. M., Millhauser, G. L., et al. (2013). A novel $\alpha$-synuclein missense mutation in Parkinson disease. Neurology 80, 1062-1064. doi: 10.1212/WNL.0b013e31828727ba

Quilty, M. C., King, A. E., Gai, W. P., Pountney, D. L., West, A. K., Vickers, J. C., et al. (2006). Alpha-synuclein is upregulated in neurones in response to chronic oxidative stress and is associated with neuroprotection. Exp. Neurol. 199, 249-256. doi: 10.1016/j.expneurol.2005.10.018

Radford, R., Wong, M. B., and Pountney, D. L. (2014). "Neurodegenerative aspects of multiple system atrophy," in Handbook of Neurotoxicity, ed R. M. Kostrzewa (New York, NY: Springer Science + Business Media), 2157-2180.

Rcom-H'cheo-Gauthier, A., Davis, A., Meedeniya, A., and Pountney, D. L. (2016). Alpha-Synuclein aggregates are excluded from Calbindin-D28kpositive neurons in Dementia with Lewy bodies and a unilateral rotenone mouse model. Mol.Cell. Neurosci. 77, 65-75. doi: 10.1016/j.mcn.2016.10.003

Recasens, A., Dehay, B., Bove, J., Carballo-Carbajal, I., Dovero, S., Perez-Villalba, A., et al. (2014). Lewy body extracts from Parkinson disease brains trigger alpha-synuclein pathology and neurodegeneration in mice and monkeys. Ann. Neurol. 75, 351-362. doi: 10.1002/ana.24066

Reznichenko, L., Cheng, Q., Nizar, K., Gratiy, S. L., Saisan, P. A., Rockenstein, E. M., et al. (2012). In vivo alterations in calcium buffering capacity in transgenic mouse model of synucleinopathy. J. Neurosci. 32, 9992-9998. doi: 10.1523/JNEUROSCI.1270-12.2012

Ritz, B., Rhodes, S. L., Qian, L., Schernhammer, E., Olsen, J. H., and Friis, S. (2010). L-type calcium channel blockers and Parkinson disease in Denmark. Ann. Neurol. 67, 600-606. doi: 10.1002/ana.21937

Rockenstein, E., Nuber, S., Overk, C. R., Ubhi, K., Mante, M., Patrick, C., et al. (2014). Accumulation of oligomer-prone alpha-synuclein exacerbates synaptic and neuronal degeneration in vivo. Brain 137(Pt 5), 1496-1513. doi: 10.1093/brain/awu057

Saito, Y., Miyasaka, T., Hatsuta, H., Takahashi-Niki, K., Hayashi, K., Mita, Y., et al. (2014). Immunostaining of oxidized DJ-1 in human and mouse brains. J. Neuropathol. Exp. Neurol. 73, 714-728. doi: 10.1097/NEN.0000000000000087

Santner, A., and Uversky, V. N. (2010). Metalloproteomics and metal toxicology of $\alpha$-synuclein. Metallomics. 2, 378-392. doi: 10.1039/b926659c

Simms, B. A., and Zamponi, G. W. (2014). Neuronal voltage-gated calcium channels: structure, function, and dysfunction. Neuron 82, 24-45. doi: 10.1016/j.neuron.2014.03.016

Sims-Robinson, C., Hur, J., Hayes, J. M., Dauch, J. R., Keller, P. J., Brooks, S. V., et al. (2013). The role of oxidative stress in nervous system aging. PLoS ONE 8:e68011. doi: 10.1371/journal.pone.0068011

Singh, A., Verma, P., Balaji, G., Samantaray, S., and Mohanakumar, K. P. (2016). Nimodipine, an L-type calcium channel blocker attenuates mitochondrial dysfunctions to protect against 1-methyl-4-phenyl-1,2,3,6tetrahydropyridine-induced Parkinsonism in mice. Neurochem. Int. 99, 221-232. doi: 10.1016/j.neuint.2016.07.003

Singleton, A. B., Farrer, M., Johnson, J., Singleton, A., Hague, S., Kachergus, J., et al. (2003). $\alpha$-Synuclein locus triplication causes Parkinson's disease. Science 302:841. doi: 10.1126/science. 1090278

Surmeier, D. J., Schumacker, P. T., Guzman, J. D., Ilijic, E., Yang, B., and Zampese, E. (2016). Calcium and Parkinson's disease. Biochem. Biophys. Res. Commun. doi: 10.1016/j.bbrc.2016.08.168. [Epub ahead of print].

Talley, E. M., Cribbs, L. L., Lee, J. H., Daud, A., Perez-Reyes, E., and Bayliss, D. A. (1999). Differential distribution of three members of a gene family encoding low voltage-activated (T-type) calcium channels. J. Neurosci. 19, 1895-1911.

Toescu, E. C., and Verkhratsky, A. (2007). Role of calcium in normal aging and neurodegeneration. Aging Cell 6:265. doi: 10.1111/j.1474-9726.2007.00299.x

Tsuboi, K., Kimber, T. A., and Shults, C. W. (2000). Calretinin-containing axons and neurons are resistant to an intrastriatal 6-hydroxydopamine lesion. Brain Res. 866, 55-64. doi: 10.1016/S0006-8993(00)02219-8

Ubhi, K., Lee, P. H., Adame, A., Inglis, C., Mante, M., Rockenstein, E., et al. (2009). Mitochondrial inhibitor 3-nitroproprionic acid enhances oxidative modification of alpha-synuclein in a transgenic mouse model of multiple system atrophy. J. Neurosci. Res. 87, 2728-2739. doi: 10.1002/jnr.22089

Wildburger, N. C., Lin-Ye, A., Baird, M. A., Lei, D., and Bao, J. (2009). Neuroprotective effects of blockers for T-type calcium channels. Mol. Neurodegener. 4:44. doi: 10.1186/1750-1326-4-44

Yamada, T., McGeer, P. L., Baimbridge, K. G., and McGeer, E. G. (1990). Relative sparing in Parkinson's disease of substantia nigra dopamine neurons containing calbindin-D28K. Brain Res. 526, 303-307.

Yunker, A. M., Sharp, A. H., Sundarraj, S., Ranganathan, V., Copeland, T. D., and McEnery, M. W. (2003). Immunological characterization of T-type voltagedependent calcium channel CaV3.1 (alpha 1G) and CaV3.3 (alpha 1I) isoforms reveal differences in their localization, expression, and neural development. Neuroscience 117, 321-335. doi: 10.1016/S0306-4522(02)00936-3

Zarranz, J. J., Alegre, J., Gomez-Esteban, J. C., Lezcano, E., Ros, R., Ampuero, I., et al. (2004). The new mutation, E46K, of alpha-synuclein causes Parkinson and Lewy body dementia. Ann. Neurol. 55, 164-173. doi: 10.1002/ana.10795

Zhou, Y., Yang, W., Kirberger, M., Lee, H. W., Ayalasomayajula, G., and Yang, J. J. (2006). Prediction of EF-hand calcium binding proteins and analysis of bacterial EF hand proteins. Proteins 65, 643-655. doi: 10.1002/prot. 21139

Conflict of Interest Statement: The authors declare that the research was conducted in the absence of any commercial or financial relationships that could be construed as a potential conflict of interest.

Copyright (c) 2016 Rcom-H'cheo-Gauthier, Osborne, Meedeniya and Pountney. This is an open-access article distributed under the terms of the Creative Commons Attribution License (CC BY). The use, distribution or reproduction in other forums is permitted, provided the original author(s) or licensor are credited and that the original publication in this journal is cited, in accordance with accepted academic practice. No use, distribution or reproduction is permitted which does not comply with these terms. 